\title{
Li isotopic and trace element compositions of spodumene as a fingerprinting tool for Li pegmatites
}

\author{
SARI LUKKARI ${ }^{1}$, YANN LAHAYE ${ }^{1}$, PENTTI \\ GRÖNHOLM $^{2}$ AND JOONAS KURTTI ${ }^{2}$ \\ Presenting Author: sari.lukkari@gtk.fi
}

${ }^{1}$ Geological Survey of Finland

${ }^{2}$ Keliber Oy

The Central Ostrobothnia Lithium Province in Kaustinen area is one of the most significant Li reserves in Europe. In 2020, the estimated mineral resources are 14,194 Mt with an average grade of $1.08 \% \mathrm{Li}_{2} \mathrm{O}$, hold by Keliber $\mathrm{Oy}$. Spodumene pegmatites occur as dyke swarms up to 450 meters in length, the width of the individual dike varying from 1 to 30 meters. None of the spodumene pegmatites are exposed, so the pegmatite exploration and diamond drilling are guided by mapping of boulder fans and the geochemistry of till samples.

Li-isotope and trace element analysis of spodumene from six $\mathrm{Li}$ pegmatite deposits and 17 boulder samples have been performed in situ by LA-MC-ICPMS and LA-SC-ICPMS. The spodumenes from the different deposits are isotopically heterogeneous, with $\delta^{7} \mathrm{Li}$ varying from -2.9 to +8.4 , but each of the deposit has distinct Li-isotopic composition. The pegmatites from the east have significantly heavier $\mathrm{Li}$ isotope proportion $\left(\delta^{7} \mathrm{Li}=+7.1 \pm 0.9, \mathrm{n}=63\right)$ than the other four deposits from the west of the province $\left(\delta^{7} \mathrm{Li}=1.1 \pm 2.0, \mathrm{n}=161\right)$. The boulder samples also show a similar bimodal distribution with two different $\delta^{7} \mathrm{Li}$ composition groups, $\delta^{7} \mathrm{Li}=2.1 \pm 0.1(\mathrm{n}=9)$ and $\delta^{7} \mathrm{Li}=6.5 \pm 0.8(\mathrm{n}=8)$.

$\mathrm{Fe}$ and $\mathrm{Mn}$ contents of the spodumene vary in every deposit, but the trace element composition is relatively homogeneous with the exceptions of $\mathrm{Cs}, \mathrm{Ba}, \mathrm{Sr}, \mathrm{Cu}, \mathrm{V}, \mathrm{Bi}, \mathrm{Co}$ and $\mathrm{U}$. These elements could be useful to understand pegmatite petrogenetic processes and fingerprint the Li pegmatites.

Combined $\mathrm{Li}$ isotope and trace element analysis of spodumene is a useful tool for characterization of $\mathrm{Li}$ pegmatites and the method can be utilized for $\mathrm{Li}$ exploration. The regional variation in geochemical, isotopic composition and the correlation between these two sets of data, will be evaluated regarding diffusion processes, magmatic and volatile fractionation together with the source of the pegmatites. 